University of Nebraska - Lincoln

DigitalCommons@University of Nebraska - Lincoln

Agronomy \& Horticulture -- Faculty Publications

Agronomy and Horticulture Department

$7-1930$

Underground Plant Development in its Relation to Grazing

J. E. Weaver

University of Nebraska-Lincoln

Follow this and additional works at: https://digitalcommons.unl.edu/agronomyfacpub

Part of the Plant Sciences Commons

Weaver, J. E., "Underground Plant Development in its Relation to Grazing" (1930). Agronomy \& Horticulture -- Faculty Publications. 464.

https://digitalcommons.unl.edu/agronomyfacpub/464

This Article is brought to you for free and open access by the Agronomy and Horticulture Department at DigitalCommons@University of Nebraska - Lincoln. It has been accepted for inclusion in Agronomy \& Horticulture -Faculty Publications by an authorized administrator of DigitalCommons@University of Nebraska - Lincoln. 


\title{
UNDERGROUND PLANT DEVELOPMENT IN ITS RELATION TO GRAZING ${ }^{1}$
}

\author{
J. E. Weaver \\ University of Nebraska
}

Grasslands or grazing lands are relatively dry lands. Drought, at least in the surface soil, is always imminent. The necessity for the seedling to make immediate and extensive contact with deeper, moister soil is apparent. The water relation is usually controlling, and the success or failure of the seedling largely depends upon its ability to develop an absorbing system adequate in extent and activity to furnish the necessary supply.

\section{Importance of Rapid Root Penetration}

The adaptation of seedlings to strike roots deeply before exposing much surface above ground, is marked. Little bluestem (Andropogon scoparius), for example, under optimum conditions for growth, extends a primary root 2 to 2.5 inches before the shoot appears above ground. The root is much branched by the end of 3 days, and, after a growth of two weeks, a depth of 6 inches and a lateral spread of 2 to 3 inches may be attained (Fig. I). Nongrassy species or forbs show a similar vigorous growth, attaining a depth of I to 2 inches 24 hours after their appearance above ground, and 5.5 to 6.5 inches by the end of 8 days (Fig. 2 ).

\section{Rôle of Roots in Competition}

Climax grasslands, whether of the dense, tall-grass or open, desert-plains type, are communities in which the least abundant necessary factor, water, is utilized in its entirety. There may be an excess for longer or shorter intervals, but the constant struggle for an adequate supply limits the population in numbers and dwarfs the individuals in stature. That even the dominant grasses are seriously handicapped by this shortage of water has been repeatedly shown by the removal of the vegetation from all but the central portions of meter quadrats. The remaining plants benefit greatly by the extra water supply thus afforded, and their growth in terms of dry weight is often more than doubled (Fig. 3). In years of excessive rainfall in Nebraska, the stature of Andropogon furcatus, A. nutans, and Spartina michauxiana reaches Io to 12 feet, about twice their usual height in lowlands in true prairie. The open spacing of grasses and other vegetation in the more xeric grasslands

${ }^{1}$ Presented at the symposium on range ecology held by the Ecological Society of America, Ames, Iowa, January I, 1930. 
of arid regions is a result of the water relation. Ecesis is difficult in such apparently bare areas since they are already fully occupied. The open area around each individual shrub or perennial herb may be several times greater than the extent of the top, but the uncovering of the root system shows that it takes tribute from most if not all of the soil concerned. Thus a life and death struggle is continuously waged where only the better equipped species survive and the best fitted will dominate.

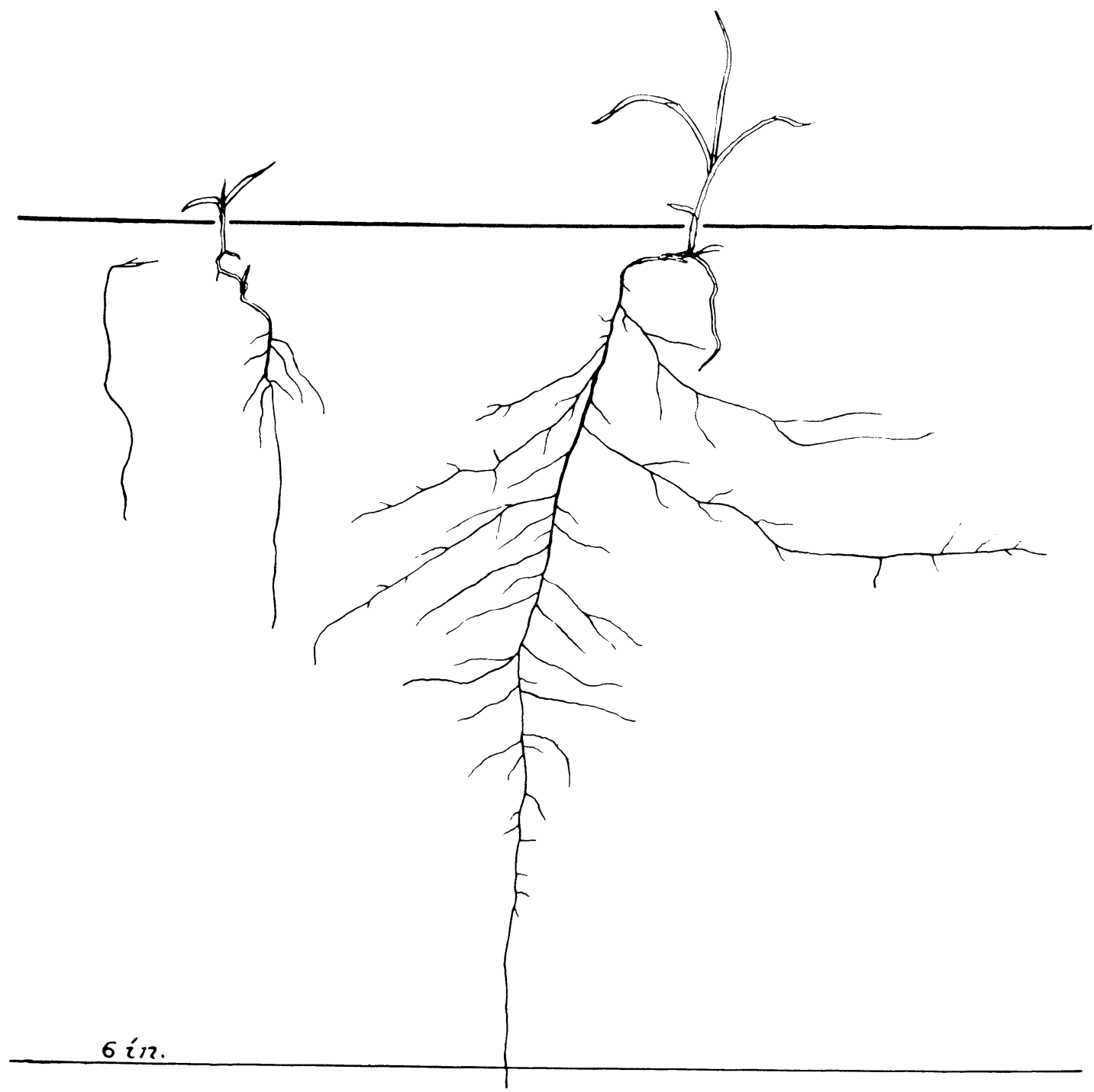

FIG. I. Development of Andropogon scoparius before its appearance above ground, and 3 and 16 days thereafter. (Data furnished by A. Blake.) 
In this bitter struggle it is the "weapons" of the competing species, to employ Warming's figure, that are of first importance. These so-called weapons comprise all the structures of the plant capable of making an effective demand upon a limited supply. The leaf bears a relation to both light

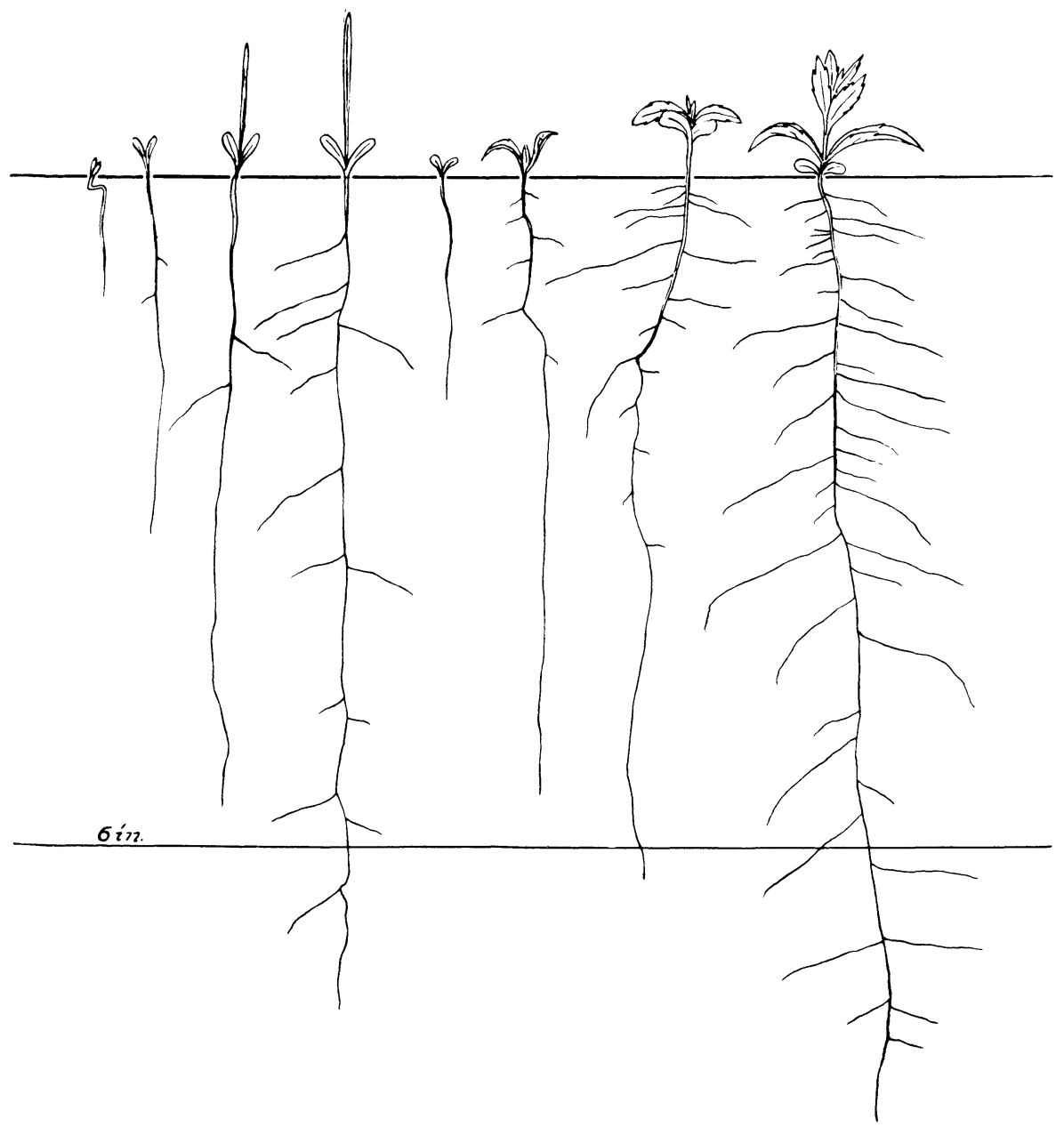

FIG. 2. Seedlings of Liatris punctata (left) I, 4, 8, and I4 days after their appearance above ground, and Kuhnia glutinosa of similar age. (Data furnished by A. Blake.)

and water, the root to water and nutrients; the rôle of the stem is chiefly secondary or indirect in that it determines the position of the leaves with respect to energy absorption and water loss. Growth is naturally of paramount importance, since it not only determines the total demand, but the time and rate at which it is made. It is expressed in germination, development, tillering or branching, size and stature, reproduction, and the maturing or ripening 
of the plant body in preparation for winter. Other less obvious but equally significant qualities are vigor and hardiness or resistance to winterkilling. Practically all of the advantages or weapons of competing species are summarized in two words, amount and rate. Greater storage in seed or rootstock, more rapid and complete germination, earlier start, more rapid growth of

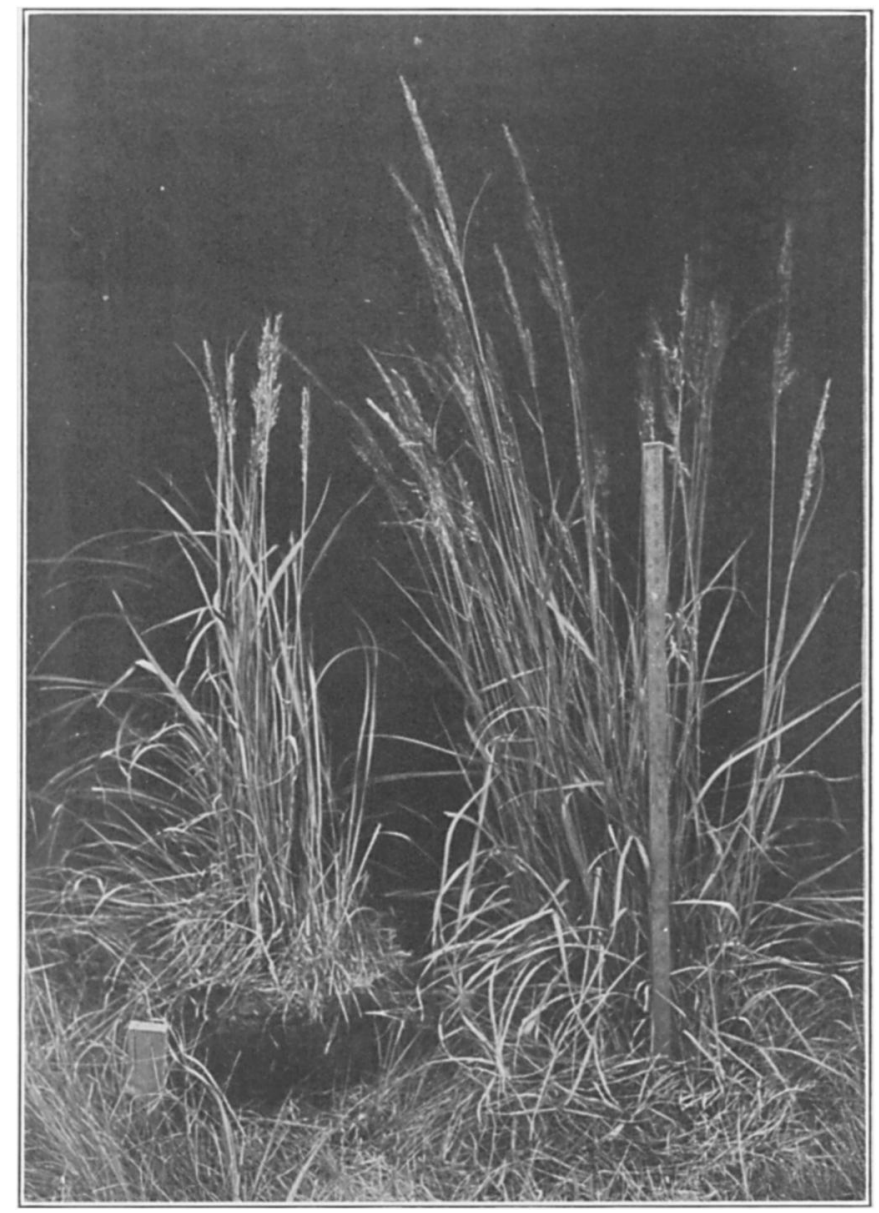

FIG. 3. Relative development of Andropogon mutans in a square meter from which its competitors had been removed in early spring, and a similar clump (left) from undisturbed grassland.

roots and shoots, taller and more branching stems, deeper and more spreading roots, more tillers, larger leaves, and more numerous flowers are all the essence of success.

The rate of germination is often decisive because of the water-root relation. Poor germination is usually slow germination and is often accompanied 
by slow growth. In dense stands of seedlings, differences of an inch or two in root length, representing the growth of but one or two days, may easily become decisive both as to the absorption of water and the consequent rapid growth that results in overtopping.

\section{Disadvantages of Annuals and Biennials}

Short-lived species, including annuals and biennials, are unable to compete successfully with the climax grasses. This fact, drawn from a study of climax and succession in the field, has been confirmed by several years of experiment. Even when the seed is sown with that of the native grasses in bare areas, species such as pigweed, ragweed, burdock, mullein, etc., are unable to germinate and win a place for themselves among the grasses in consequence of seed produced the preceding year. They are not equipped to compete with the grasses. This accords with the almost complete absence of annuals in the climax matrix of the several prairie associations. They never occur in the climax except in disturbed places, and are abundant in the desert-plains and bunch-grass associations only in seasons of high rainfall or particularly during the period of winter rainfall when the climax species are making fewer demands upon the water supply.

\section{Importance of Tiller Formation}

The ability to form tillers readily, and thus produce a clump or mat, is an extremely important weapon in winning a place in grassland. Tillering in all species studied begins simultaneously with the development of the secondary root system, and usually 3 to 6 weeks after germination. The period of tillering, before new roots become well established in the moist layers of soil, is a very critical one for the plant. The transpiring area has developed somewhat ahead of the root system in contact with deeper soil. Drought at this time often causes great mortality. Next to germination itself, it is the most critical time in the life of the plant. Where a little erosion occurs, it may be plainly seen that the seedling is literally hanging on to life by a single thread (Fig. 4). But once the secondary root system is established, the chances for the completion of ecesis are fairly certain.

The degree of tillering is a fair inclex to the rapidity of growth and extent of the root system. Crowding delays or prohibits tillering. Some plants, like Andropogon nutans, when grown in dense cultures tiller with difficulty and may develop only single stalks even after a growth of several years. Hence in the prairie matrix they are otten of only minor importance. Others such as the dropseed (Sporobolus longifolius) tiller profusely, soon forming dense clumps. Sporobolus rapidly develops a root system, which although not deep, is dense, widely spreading, and profusely branched. A soil area of 6 to 7 square feet may be preempted to a depth of 18 inches by the roots of a single bunch. It is exceptionally well fitted to secure water from dry soil, and during years of drought its rôle as a dominant is especially conspicuous. 


\section{IMPORTANCE OF RHIZOMES}

Possession may not be nine points of the law but it is the law among competing dominants. In many species possession is obtained by supplementing early tillering with the production of rhizomes. Agropyron smithii, for example, occupies the soil beneath the clump only, but at an early age rhizomes

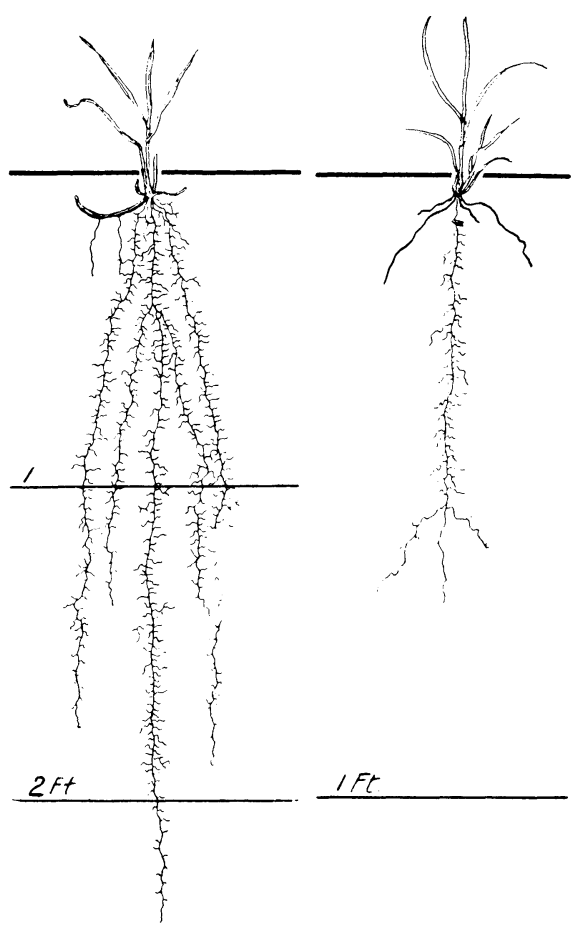

FIG. 4. (Left) Roots and rhizomes of a 3-months-old Agropyron smithii. (Right) Sporobolus longifolius tillering and developing a secondary root system at the age of 6 weeks.

with their new roots appear, and the sphere of its activities is rapidly extended (Fig. 4). The rhizome is a valuable asset in permitting the species to consolidate its gains. The bunch and sod life-forms, displayed by dominants of grassland, are extremely important both in permitting the plant to grow and extend its area in semiarid and arid regions and in restricting the abuses of overgrazing. In bunch grasses, the new stems, which originate a short distance below the surface of the soil, grow up more or less parallel with the parent culm and inside of the leaf sheath. In sod grasses, the end of the new branch forces its way through the base of the leaf sheath and migrates some distance from the parent before coming up. Meanwhile it may develop a new set of roots. In both types of vegetative propagation a better and 
more prolonged provision for the offspring is assured; the offspring become apparent when the clump or sod breaks up. The parent furnishes water and food until the new individual is established, often in the presence of competitors. Once in possession, the rhizomes of wheat grass, bluestem, etc., remain when other species have been trampled out and the soil laid bare. They endure because of their tenacious rootstocks, and remain in possession ready to resume control when decreased grazing or good years permit.

The importance of vegetative propagation is clearly shown where patches of buffalo grass occur in overgrazed tall-grass prairie. Examination shows that these areas almost invariably consist either of all staminate or all pistillate plants. Quadrat studies have shown that, with few exceptions, each area has grown from a single plant and that the spread is due to stolons and rhizomes and not to seedlings. Bouteloua and other short grasses increase in a similar manner under conditions where the chances for successful ecesis of seedlings are extremely unfavorable. Whatever merits sexual reproduction may have in providing variations which enable the race to survive major vicissitudes of the environment, its absence does not preclude efficiency as long as conditions remain relatively uniform.

\section{Underground Parts and Plant Vigor}

The increased vigor of the plant during successive years is clearly related to the better development of the parts under ground, and especially to the reserve supply of foods accumulated in them. Seedlings of buffalo grass (Bulbilis dactyloides) planted in early spring were an inch high by the second week in June of the first year, 2 inches high the second year, and 4 inches on the same date the third year. Similar data for little bluestem (Andropogon scoparius) are I, 7 , and I2 inches, respectively; for western wheat grass (Agropyron smithii) 3, 9, and I4 inches; while needle grass (Stipa spartea) gave even greater differences, reaching respectively heights of 4 , I2, and 24 inches. Among dicotyledonous species, where roots and rhizomes are larger and storage capacity thus greatly increased, the rate of development is marked. Prairie sunflowers (Helianthus rigidus), for example, reached a height of $I$ inch early in June of the first year, by the second year the plants were 12 inches tall, and on the same date the third year, 20 inches.

\section{Relation of Root Development to Winterkilling}

Winterkilling of seedling grasses is extremely important, and must be considered in the improvement of a depleted range. From experimental evidence it seems almost certain that death is not due to cold but to the results attending the process of the desiccation of the tissues. Here again the extent of the root system bears a direct relation to the water supply. That winterkilling is often greatest in low, wet soils is no argument against the facts, for here the seedlings have been unable to mature or ripen before the oncoming of cold. Great differences exist among species in their resistance 
to freezing, due to differences in water-imbibing substances (pentosans, mucilages, pectic bodies), osmotic pressures, etc., and ability to harden. Yet the fact remains that in the same species grown under the same conditions a direct relation has been determined between winterkilling and root development. In thick stands of suppressed and dominant seedlings, invariably the more vigorous plants with the best developed underground parts are injured least. Experiments at Lincoln, Nebraska, have shown that although 40 to 60 per cent of year-old seedling grasses may die the first winter, after a second season's growth the loss from winter injury is rare. By this time the much-branched roots extend far into the deeper soil, and the underground parts are filled with reserve supplies of food (Clements, Weaver, and Hanson, '29).

A close correlation between winter survival and root development has been found in Hungarian brome grass, timothy, and Kentucky blue grass (Keim and Beadle, '27). Where plantings were made at I 5 -day intervals, beginning August I, the roots of brome grass attained depths of I8, I6, I I, I0, 7, and I.5 inches respectively, and the number of roots and their lateral spread were in approximately the same ratio. The percentages of survival in the same sequence were $9 \mathrm{I}, 84,42,56,7$, and $\mathrm{O}$. With legumes the correlation was even closer. Alfalfa, planted on August I and at I5-day intervals thereafter, reached depths of 42, 30, I9, and Io inches. Root diameters, which give a general idea of the amount of food accumulated in the seedlings, were 4.0, 2.8, I.O, and $0.8 \mathrm{~mm}$. Winter survival in the same sequence was 75,32 , 1 , and o per cent. Seedlings that did not extend into the second foot of soil succumbed (Fig. 5). Similar results were obtained with the clovers. The advantage of early seeding of winter wheat in the true prairie climate is commonly known, the best winter survival and highest yields (except for occasional losses due to insect damage) being attained when the wheat is planted as early as September 22.

Certain varieties of plants have roots well adapted physically to the strains imposed upon them by the alternate freezing and thawing of the soil. In the case of flax, a direct correlation has been established between the extensibility and tensile strength of roots and winter survival (Kokkonen, '27). Similar relations may be found to exist among species of natural grasslands. The relative efficiency of priniary and secondary root systems of range grasses, their length of life in the various species, and numerous similar problems await solution. Good progress along these lines is being made with the roots of cultivated cereals, and such studies indicate the clirection of successful attack upon kindred problems of the range (Krassovsky, '25, '27).

\section{Differences in Root Systems and Tops in Relation to Competition}

No species is equipped with all the possible advantages, although the most successful have some developed to a marked degree. The finely branched, widely spreading root systems of species of upland true prairie are in marked contrast to the coarser, more vertically penetrating roots in lowland, which are 
also more poorly furnished with laterals. The usual sequence from wet areas to dry hilltops is slough grass (Spartina michanxiana), tall panic grass (Panicum virgatum), big bluestem (Andropogon furcatus), Indian grass (A. nutans), little bluestem (A. scoparius), and needle grass (Stipa spartca). There is also a clear transition from the less efficient to the more efficient absorbing organs in the same sequence as regards both thorough ramification of the soil and relative absorbing area. That big bluestem is a dominant in low prairie,

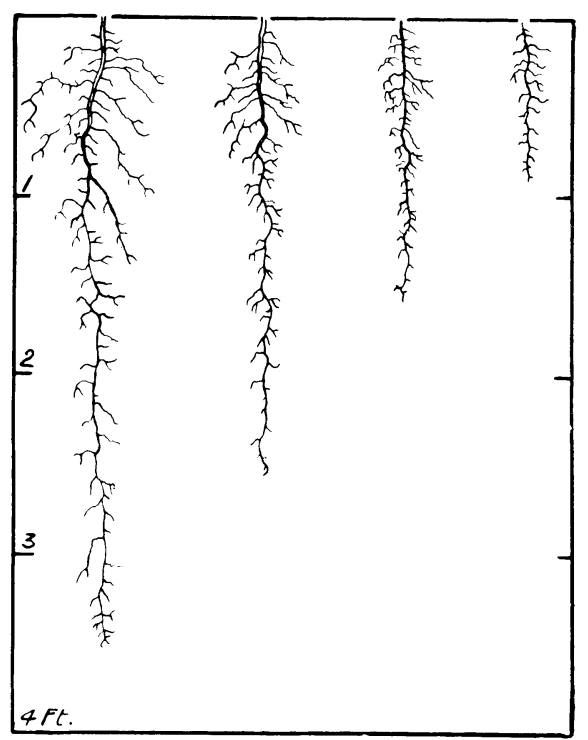

FIG. 5. Root systems of alfalfa planted on August I (left) and at I5-day intervals thereafter, and excavated on November 20 of the same year. (Redrawn from Keim and Beadle, '27.)

and little bluestem in upland, is believed to be due primarily to adaptations of their rooting habits. Proceeding to the still drier areas of mixed prairie, short-grass and desert plains, the wonderfully developed network of fine absorbing roots of the short grama grasses (Bouteloua gracilis and B. hirsuta), buffalo grass (Bulbilis dactyloides), Muhlenberg's ring grass (Muhlenbergia gracillima), etc., far excels that of any of the preceding. Conversely, whether or not a species will become established and flourish in the wet meadows of range lands is largely determined by the ability of its roots to endure deficient aeration.

The methods employed by different species to secure a place in the vegetational cover are very diverse. Extreme differences are illustrated by a blazing star (Liatris punctata) and the prairie false boneset (Kuhnia glutinosa). The former develops a meagerly branched taproot and a pair of grass-like leaves; the latter grows rapidly, producing a widely spreading root system and a large photosynthetic area (Fig. 6). Liatris grows slowly, is very tol- 


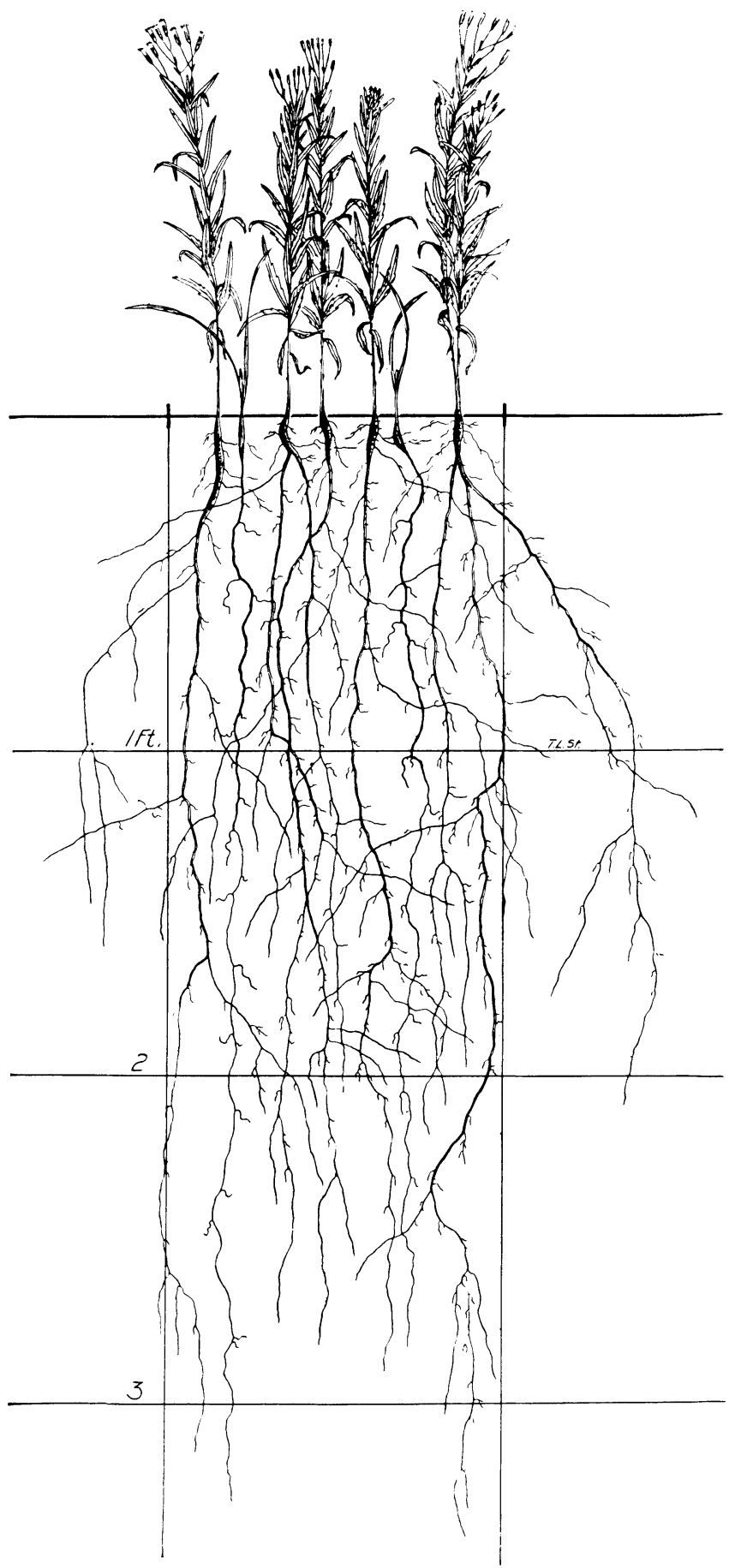

FIG. 6. Bisect through a mixed culture of Kuhnia glutinosa and Liatris punctata at the end of the first summer. 
erant of shade, and early accumulates a reserve supply of food. Kuhnia may produce viable seed the first year and regularly thereafter, since its deeply penetrating underground parts furnish unfailing supplies of water and nutrients. Because of its vigorous growth, due to much stored food, its leaves are exposed to full sunlight. In competition with the grasses, the advantage of rapid development results in absorption at deeper levels and the more favorable position as regards absorption of energy. It frequently suppresses its grass competitors for two or three years. Liatris relies upon its great tolerance, it is protected from extreme transpiration; it starts anew each year on accumulated food, and may not produce seed for three or more years. But ultimately each attains its place in the sun. Brauncria pallida and Amorpha canescens are somewhat similar to the blazing star; Helianthus rigidus and Solidago rigida employ, as does Kuhnia, the weapon of vigorous development.

The goldenrod (Solidago rigida) is illustrative of a weedy species and, in fact, constitutes one of the worst weeds in overgrazed true prairie. When germinated in mixed cultures with seedlings of dominant grasses, it readily gains control and suppresses the grasses. Its roots develop rapidly, penetrate deeply, and at the same time spread widely and form an effective network in the surface soil. Much food is stored underground, and it starts growth early in spring, usually before its competitors. It spreads by stout rhizomes, making very dense groups which are a feature of its keen competition.

\section{Light And Moisture}

Although light is not usually considered a limiting factor in grasslands, yet it often plays an important part in the development of seedlings. Much may be learned by following the struggle of blue grama grass and a tall grass, such as Andropogon nutans, during the vicissitudes of alternating wet periods and drought, and humid and arid summers. Drought favors the short grass since its more efficient absorbing system can rob the other grass of water. Rains result in the Indian grass overtopping and suppressing the grama. The death struggle for supremacy may go on for years, the climate controlling the outcome. In mixed prairie it is never decisive, and the competitors wage an unceasing war-short grasses and grass-like sedges arrayed against the taller bluestems, wheat grasses, and needle grass. The fight for the limited water supply is won by the short grasses in the plains; the tall grasses are easy victors in true prairie. But the struggle still goes on, short grass against its kind and tall grasses against their competitors, often their own offspring.

\section{EFFect of Overgrazing}

Upon such a field of battle is introduced the disturbing element of overgrazing. Small wonder that the equilibrium established by long development and climate under moderate grazing is upset, often with disastrous results to the vegetation.

Seedlings weakened by the grazing of the tops extend their roots less 
deeply and are more apt to die of drought. Left unprotected through the more or less complete removal of the plant cover, they are more likely to be injured by trampling. The increased erosion is decidedly to their disadvantage, and, lacking the partial shading and protection from wind and aerial drought afforded by the plant cover, they find growth increasingly difficuit. Experiments have shown that seedlings of prairie plants may become established on the margins of bared areas, especially the southern ones, while failing to ecize where the plant cover furnishes no protection (Clements and Weaver, '24).

Under grazing, the advantage gained by early germination and growth may become a severe handicap. The needle grass (Stipa spartea), and others of the genus such as comata, pennata, setigera, etc., have disappeared ander the impact of overgrazing, except in protected places. This is chiefly in consequence of their early growth in spring at a time when other grasses have grown but little or not at all. Such grazing has greatly reduced their later growth and seed production, and placed them at an increased disadvantage with such competitors as Andropogon and other tall grasses that start materially later. The fate of Stipa sparted is likewise overtaking Kocleria cristata in the same region, owing to its starting somewhat later.

Often associated with early growth is the weapon of great stature. When subjected to grazing, this too may become a decided disadvantage. Rapidly developing forbs, if eaten, may disappear, being replaced in part by those of lower stature that develop more slowly. Psoralea is an example of the former and Antennaria of the latter.

Tillering may be retarded by grazing. Trampled, packed, and eroded soils are in poor physical condition for new root formation. As a result growth is poor, less forage is produced, little food is stored, rhizome development is limited, and losses due to winterkilling or drought in subsequent years are greatly increased. Hence on mountain ranges, and often elsewhere, it pays to keep the stock from the seeded portion of the range during the entire first season.

The rhizome habit is a wonderful asset, enabling grasses to persist under severe grazing and trampling. In pastures subjected for years to overgrazing, which was far more severe than that usually encountered on the open range, rhizomes of the Andropogons were still intact. Under protection, they gave rise to a weak growth of foliage, but in three years they had regained their full vigor, and the tops their usual height. The severe abuse to which wheat grass may be subjected and the endurance of the rhizomes under severe trampling are well known. When all the aboveground parts disappear the soil is still potentially occupied. Invading weedy species are certain to be driven out, when their allies-the hungry, grazing animals-are withdrawn or materially reduced in numbers. But if overgrazing continues and the rhizomes and roots are starvel, the sod becomes broken, the water and light relations are profoundly modified, and marked changes in the plant populations may follow. 


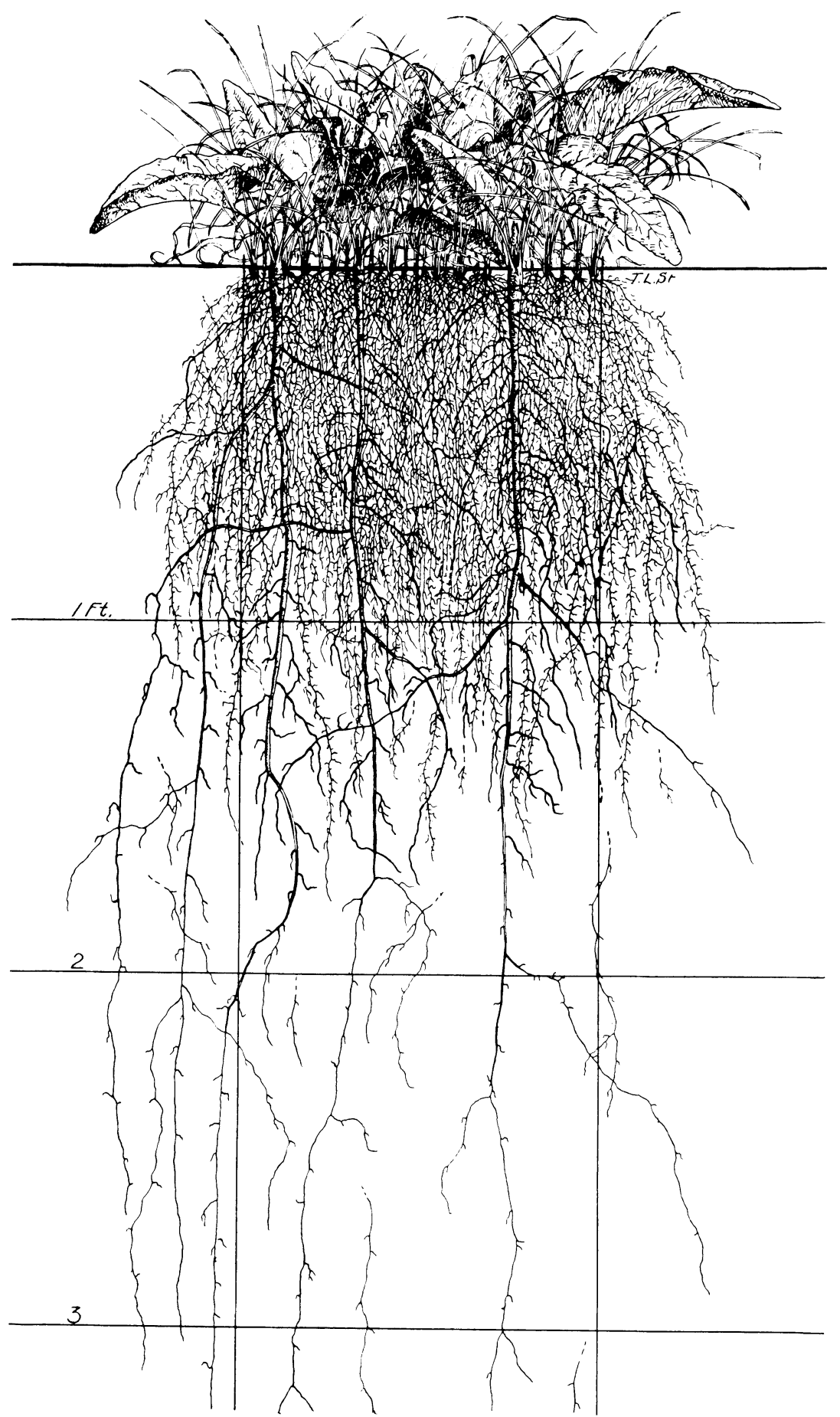

FIG. 7. A weed in grassland, Arctium lappa minus, in competition with Andropogon nutans. Although the latter has the disadvantage, both in depth of absorbing system and the relation to light, its dense, efficient root system enabled it to completely rout the invader. 
Light overgrazing is marked by a decrease in the abundance of the more valuable species of grasses (needle grasses, wheat grasses, etc.) and is accompanied by an increase in the less valuable ones (wire grass, etc.). Short grasses, if present, usually thrive and, as in true prairie, widely extend their area. The vigor and abundance of societies of sages, goldenrods, asters, legumes, etc., formerly held in check by the grasses, greatly increase. Further overgrazing is indicated by the abundance of long-lived unpalatable or well protected species such as gumweed, yarrow, ironweed, vervain, thistle, and cactus. But when the cover is laid bare, annual weeds and short-lived, umpalatable perennials find a habitat in which they can grow, suffering little competition with better equipped species. But when some of the overabundant grazing animals are withdrawn and their numbers thus materially decreased, succession restores the range to its rightful owners. In this struggle, continued through the years, roots and rhizomes play a leading part (Fig. 7). Not at once will the almost vanquished grasses repopulate the area. The first and second growing seasons are often given over to food accumulation in the underground parts. The vigor of roots and rhizomes bears a direct relation to the production of viable seed for repopulating the range. If parts below ground are weak the seed crop will be small, late in ripening, and of low viability.

\section{SumMARY}

Underground plant parts play a rôle of major importance in the starting of plant populations. Natural grasslands are relatively dry lancls; rapid germination and elongation of the primary absorbing system are requisite to successful establishment. Water is the major limiting factor to growth, hence the amount of forage produced depends in a large measure upon the extent and efficiency of the root system. The production of tillers is successful only when the secondary root system penetrates into the moist soil and meets the increased demands for water. Seedlings weakened by too severe grazing are liable to succumb, especially if the soil is compacted by trampling or eroded as a result of the disturbance of the plant cover.

Persistence of the vegetation through the arid summer, and through the drought and cold of winter, is directly related to the development of underground plant parts. Among grasses of prairie and plains, those of uplands and arid soils usually have roots that are more extensive in proportion to tops and possess finer and more numerous branches than those of lowlands and less arid soils. Plants with poorly established root systems and little food stored therein are less resistant to winterkilling. More rapid and earliergrowth of long-lived grasses and other herbs results from abundant food accumulations in underground parts. Overgrazing results in poorer root growth, and permits of little food accumulation; the plants are more apt to die of drought and cold.

Underground plant development permits of an increase in territory and of 
resistance to invaders. The bunch and sod habits, resulting from tillering and rhizome production, increase the plant cover, even when conditions are unfavorable for the establishment of seedlings. Erosion is decreased, and invading annuals are at great disadvantage unless the cover is broken by overgrazing. Rhizomes persist even when all the aboveground parts are eaten and the soil trampled bare. An efficient absorbing system frequently outweighs the advantage of greater stature. Vigor of growth and the amount and viability of seed are directly related to the food supply available in underground parts. Poor seed may result in slow germination and poor establishment.

\section{Literature Cited}

Clements, F. E., and Weaver, J. E. 1924. Experimental vegetation. Carnegie Inst. Wash. Pub. 355.

Clements, F. E., Weaver, J. E., and Hanson, H. C. 1929. Plant competition. Carnegie Inst. Wash. Pub. 398.

Keim, F. D., and Beadle, G. W. 1927. Relation of time of seeding to root development and winter survival of fall seeded grasses and legumes. Ecology, 8: 251-264.

Kokkonen, P. 1927. Über das Verhältnis der Winterfestigkeit des Roggens zur Dehnbarkeit und Dehnungsfestigkeit seiner Wurzeln. Pp. 1-45.

Krassovsky, Irene. 1925. Physiological activity of seminal and nodal roots of crop plants. Soil Science, 21: 307-324.

Krassovsky, I. V. 1927. Physiological activity of the seminal and nodal roots of crop plants. Records Leningrad Agr. Inst., 4: 175-222. 